\title{
Op de grens van het vreemdelingentoezicht: discretionaire beslissingen binnen het Mobiel Toezicht Veiligheid
}

\author{
Jelmer Brouwer, Maartje van der Woude \& Joanne van der Leun
}

\begin{abstract}
In deze bijdrage staat het Mobiel Toezicht Veiligheid (MTV) zoals dat in de Nederlandse grensgebieden wordt uitgevoerd door de Koninklijke Marechaussee centraal. Het MTV heeft een complexe wettelijke en beleidsmatige grondslag, waarbij sprake is van een vervlechting van vreemdelingrechtelijk toezicht en enkele vormen van strafrechtelijke handhaving. Dit roept de vraag op hoe de street-level Marechaussees die betrokken zijn bij de uitvoering van het MTV hun eigen taak zien en welke gevolgen dit heeft voor de beslissingen die zij maken. De resultaten laten zien dat veel marechaussees het vangen van 'boeven' als een belangrijk onderdeel van hun taak zien en dat zij regelmatig op creatieve wijze gebruikmaken van hun ruime bevoegdheden om dat doel te bereiken. Dit heeft gevolgen voor de transparantie van beslissingen en de rechtspositie van betrokken.
\end{abstract}

\section{Introductie}

De Koninklijke Marechaussee (hierna: KMar) voert binnen haar taak als 'grens (vreemdelingen) politie' onder andere het Mobiel Toezicht Veiligheid (hierna: MTV) uit. Dit zijn mobiele identiteitscontroles die sinds de inwerkingtreding van het verdrag van Schengen in 1995 worden uitgevoerd in de grensgebieden met België en Duitsland. Sinds het uitbreken van de vluchtelingencrisis staan deze controles in toenemende mate in de aandacht. ${ }^{1}$ Het MTV valt onder het operationeel vreemdelingentoezicht zoals geregeld in artikel 50 Vreemdelingenwet 2000 (hierna: VW 2000). Waar deze vorm van vreemdelingentoezicht oorspronkelijk enkel was gericht op het tegengaan van illegaal verblijf, omvat de officiële doelstelling inmiddels ook het bestrijden van mensensmokkel en identiteitsfraude (Van der Woude, Dekkers \& Brouwer, 2015). Het betreft een proactieve controlebevoegdheid, wat betekent dat personen gecontroleerd kunnen worden zonder dat er sprake hoeft te zijn van een redelijk vermoeden van illegaal verblijf of een strafbaar feit (Corstens \& Borgers, 2014: 297). De marechaussees die belast zijn met de uitvoering van het MTV hebben dan ook veel discretionaire ruimte om te beslissen wie zij stoppen voor een controle en wie zij nader willen onderzoeken. Vanuit de wetenschap bestaat er traditioneel veel belangstelling voor de discretionaire beslisruimte van politieagenten (Brown, 1981; Maynard-Moody \& Musheno, 2000; Mendias \& Kehoe, 2006; Phillips, 2015; voor recente Neder-

1 Het veldwerk voor deze bijdrage is uitgevoerd voordat de vluchtelingencrisis daadwerkelijk het nieuws begon te beheersen. 
landse studies, zie: Çankaya, 2012; Kleijer-Kool \& Landman, 2016; Landman, 2015). Tegelijkertijd is het opvallend dat er over het optreden van actoren binnen het vreemdelingentoezicht tot op heden relatief weinig studies zijn verschenen (zie voor enkele uitzonderingen: Aas \& Gundhus, 2015; Casella Colombeau, 2015; Pratt \& Thompson, 2008; Weber, 2011). Dit is des te opmerkelijker in het licht van het proces van crimmigratie, waarmee gedoeld wordt op de toenemende vervlechting van strafrechtelijk en vreemdelingrechtelijk handhaven en toezichthouden (Staring, 2012; Stumpf, 2006; Van der Leun, 2010; Van der Woude, Van der Leun \& Nijland, 2014). Dit proces is zichtbaar op het niveau van het politieke en publieke discours, het niveau van wetgeving, maar ook op het uitvoeringsniveau en heeft onder meer tot gevolg dat zowel immigranten als criminelen worden gezien als bedreigingen waartegen opgetreden moet worden met alle beschikbare middelen (Chacón, 2012; Stumpf, 2006; Van der Leun, Van der Woude \& De Ridder, 2013).

Verschillende auteurs zien vooral de beslissingen van street level officers (Lipsky, 1980) - en in het bijzonder de mogelijkheid om mensen te stoppen voor een controle - als de belangrijkste factor in het crimmigratieproces (Motomura, 2011; Pratt, 2010; Stumpf, 2006). Er is recentelijk dan ook meermaals benadrukt dat er een sterke behoefte is aan empirisch onderzoek naar de dagelijkse praktijk van agenten die opereren als grens- of vreemdelingenpolitie (Cote-Boucher, Infantino \& Salter, 2014; Loftus, 2015) Loftus (2015) raadt daarbij aan om te putten uit de rijke literatuur op het gebied van reguliere politieambtenaren en na te gaan in hoeverre de centrale bevindingen daarvan ook van toepassing zijn op grenspolitieagenten.

In deze bijdrage gaan we nader in op de wijze waarop marechaussees die betrokken zijn bij de uitvoering van het MTV, invulling geven aan hun discretionaire beslisruimte. We richten ons hierbij expliciet op de wisselwerking tussen vreemdelingentoezicht en strafrechtelijke handhaving en de gevolgen die dat heeft voor de rechtswaarborgen. Juist die waarborgen kunnen onder druk komen te staan wanneer rechtshandhavers naar believen kunnen kiezen uit verschillende typen wetgeving (Sklansky, 2012; Van der Woude et al., 2015). Zoals elders uiteengezet, heeft het MTV een complexe wettelijke en beleidsmatige grondslag ten aanzien van de precieze doelstelling van het instrument, waarbij sprake is van een vervlechting van vreemdelingrechtelijk toezicht en strafrechtelijke handhaving (Van der Woude et al., 2015). Dit roept de vraag op hoe deze onduidelijkheid omtrent de exacte taakstelling en bijbehorende bevoegdheden - passend binnen het genoemde proces van crimmigratie - wordt geïnterpreteerd door de ambtenaren op straatniveau en welke gevolgen dit heeft voor de wijze waarop zij hun taak uitvoeren. De vraag die in deze bijdrage centraal staat, luidt dan ook:

Hoe zien street level marechaussees die betrokken zijn bij de uitvoering van het Mobiel Toezicht Veiligheid hun eigen taakstelling, en in hoeverre en hoe is dit van invloed op de wijze waarop zij in de praktijk invulling geven aan de discretionaire beslisruimte die zij hierbij genieten? 
Op de grens van het vreemdelingentoezicht: discretionaire beslissingen binnen het Mobiel Toezicht Veiligheid

Deze vraag zal worden beantwoord op basis van uitgebreid empirisch onderzoek, waaronder ruim 800 manuur aan observaties tijdens MTV-controles en focusgroepgesprekken met uitvoerende marechaussees die betrokken zijn bij het MTV. Hierna gaan we eerst nader in op de theoretische grondslag voor dit stuk door het verder uiteenzetten van de onderlinge samenhang tussen de begrippen discretionaire beslisruimte en crimmigratie. Vervolgens geven we enige achtergrond en context door de praktijk van het MTV en de discretionaire ruimte die de marechaussees daarbij hebben te beschrijven. $\mathrm{Na}$ een bespreking van de gehanteerde methodologie die ten grondslag ligt aan het onderzoek gaan we in op de beantwoording van de centrale vraag. Daartoe zullen we eerst laten zien dat de marechaussees aangeven te moeten laveren tussen vreemdelingentoezicht en strafrechtelijke handhaving, om vervolgens twee verschillende stijlen onder de marechaussees te identificeren en in te gaan op de manier waarop dit zich in beslissingen in de praktijk vertaalt. Het artikel wordt afgesloten met een conclusie en discussie.

\section{Discretionaire beslisruimte en crimmigratie}

De marechaussees die belast zijn met de uitvoering van het MTV lijken in veel opzichten op reguliere politieagenten. Niet alleen vertegenwoordigen zij de overheid in dagelijkse interacties met burgers, tevens beschikken zij over een ruime mate van discretionaire ruimte om de wettelijke kaders en het formele beleid te vertalen naar de praktijk. Zij dienen de vaak abstracte, multi-interpretabele en soms zelfs tegenstrijdige doelstellingen die op beleids- en organisatorisch niveau worden geformuleerd toe te passen op concrete situaties (Lipsky, 1980; Van der Woude et al., 2015; Van Gestel \& De Poot, 2014). In veel gevallen dienen ze gebruik te maken van hun discretionaire vrijheid om concrete situaties te interpreteren, prioriteiten te stellen en beslissingen te nemen. Hoewel een ruime discretionaire ruimte voor street level ambtenaren enerzijds kan leiden tot rechtvaardigere beslissingen wanneer individuele ambtenaren door het niet of anders toepassen van de wet bepaalde ongewenste gevolgen kunnen voorkomen die de wetgever niet had voorzien (Schneider, 1992), kan het anderzijds ook resulteren in rechtsongelijkheid en zelfs onrechtmatige beslissingen (Maynard-Moody \& Musheno, 2000). Daarbij geldt over het algemeen dat hoe onduidelijker de officiele beleidsdoelen zijn, hoe meer ruimte er ontstaat voor ambtenaren om naar eigen inzicht beslissingen te nemen. Zo vond Bastien (2009) in een recente studie naar het Spaanse immigratiebeleid dat ambigue doelstellingen leidden tot meer discretie onder de ambtenaren die dit beleid moesten implementeren. Vage beleidsdoelen kunnen er dan ook toe leiden dat bijvoorbeeld persoonlijke overtuigingen of individuele beroepsopvattingen het optreden van street level ambtenaren gaan beïnvloeden, en maken het bovendien moeilijker om deze uitvoerende ambtenaren verantwoording te laten afleggen over hun beslissingen.

In de politieliteratuur is er de laatste jaren veel aandacht voor individuele en situationele factoren die van invloed kunnen zijn op de wijze waarop politieagenten invulling geven aan hun discretionaire beslisruimte tijdens het uitvoeren van 
proactieve controles (voor een overzicht, zie: Dekkers \& Van der Woude, 2014; Johnson \& Morgan, 2013). Uit deze literatuur komt naar voren dat discretionaire beslissingen van politieagenten niet los gezien kunnen worden van hetgeen Hawkins (2014) het decision field noemt: het geheel aan wettelijke kaders, beleidskeuzes en richtlijnen dat het kader vormt waarbinnen professionals discretionaire beslissingen nemen. Ook zijn zogenoemde 'working rules', de interne cultuur van de politieorganisatie en informele normen en waarden van individuele agenten van invloed op de beslissingen om bijvoorbeeld iemand wel of niet te stoppen (Alpert, Macdonald \& Dunham, 2005; Dunham, 2005; Quinton, 2011; Stroshine, Alpert \& Dunham, 2008). Er wordt in dat kader ook wel gewezen op de verschillende politiestijlen die agenten hebben en de invloed die dit heeft op hun optreden (De Maillard, Hunold, Roché \& Oberwittler, 2016; Kleijer-Kool, 2010; Van der Torre, 1999; Wilson, 1978). Terpstra en Schaap (2011) onderscheiden in de Nederlandse context drie verschillende politiestijlen: ordehandhaver/dienstverlener, crime fighter en de professionele werkstijl. Zij stellen daarnaast dat voor bijna alle Nederlandse politieagenten actie en spanning een belangrijke aantrekkingskracht van het werk vormen en dat agenten een sterke motivatie hebben om 'de normen in de samenleving over goed en kwaad te bewaken en de zwakken te beschermen' (p. 188).

Halderen en Lasthuizen (2013) beweren dat dit streven om bepaalde organisatiedoelen of maatschappelijke belangen te bereiken regelmatig leidt tot een creatief gebruik van bevoegdheden, vooral wanneer er sprake is van beperkte bevoegdheden of onduidelijke wetgeving. Dit sluit aan bij de bewering van MaynardMoody en Musheno (2000) dat beslissingen van street level ambtenaren niet zozeer bepaald worden door regels, training en procedures, maar vooral door het streven naar rechtvaardigheid. Zij stellen dat deze functionarissen niet zozeer regels en procedures inzetten om tot beslissingen te komen, maar veelal eerst een oordeel vormen over een burger of cliënt en zich vervolgens tot regels en procedures wenden om hun beslissing uit te voeren of te rationaliseren. Portillo en Rudes (2014: 323) beweren dan ook dat meer regels en procedures paradoxaal genoeg zelfs tot meer discretie kunnen leiden:

'With more rules in place, street level bureaucrats have greater discretion to determine which rule(s) to apply in a given situation. More, and contradictory, rules leave more options available for application and less the ability to monitor their application.'

Hoewel een en ander natuurlijk afhangt van de wijze waarop die regels geïmplementeerd worden, is dit niettemin een interessante observatie met het oog op het in de inleiding reeds benoemde proces van crimmigratie. Volgens David Sklansky (2012) kan crimmigratie niet los worden gezien van een bredere tendens van wat hij ad hoc instrumentalisering noemt. Hiermee doelt hij op een manier van denken over het recht en juridische instanties waarin formeel onderscheid tussen rechtsgebieden van ondergeschikt belang is en overheidsfunctionarissen per individueel geval kunnen kiezen welk instrument het meest effectief is om een probleem op te lossen. Deze manier van denken wordt volgens hem sterk beïnvloed 
Op de grens van het vreemdelingentoezicht: discretionaire beslissingen binnen het Mobiel Toezicht Veiligheid

door scepticisme ten aanzien van de noodzaak en mogelijkheid om de discretionaire beslisruimte van uitvoeringsambtenaren te beperken. Ook in Nederland is de ontwikkeling naar een bedrijfsmatig en instrumentalistisch strafrechtsysteem in de laatste decennia duidelijk waarneembaar (Van der Leun et al., 2013; Van der Woude et al., 2014).

Volgens Sklansky is deze instrumentale benadering van het recht onlosmakelijk verbonden met crimmigratie. Door de toenemende vervlechting van strafrechtelijke handhaving en vreemdelingentoezicht hebben street level ambtenaren een breder spectrum aan mogelijkheden om een persoon te stoppen of nader te onderzoeken, hetgeen hun discretionaire ruimte vergroot. Sklansky spreekt over een gereedschapskist van juridische instrumenten die handhavers kunnen inzetten om ongewenste individuen aan te pakken, of dat nu criminelen of migranten zijn. Vanwege de instrumentele overwegingen en de nadruk op effectiviteit krijgt de handhaving niet alleen een sterk ad hoc karakter, ook raken rechtswaarborgen daarbij op de achtergrond. Bovendien kunnen de vele mogelijkheden die handhavers tot hun beschikking hebben om op te treden al snel tot een gebrek aan transparantie leiden, doordat 'er op deze wijze niet of nauwelijks inzicht geboden wordt in de gronden waarop individuele ambtenaren hun keuzes en beslissingen baseren' en deze ambtenaren vaak weinig verantwoordelijkheid over hun handelen hoeven af te leggen zolang hier geen formele klachten over worden ingediend (Van der Leun et al., 2013: 227).

\section{Discretionaire ruimte binnen het Mobiel Toezicht Veiligheid}

Het MTV is in 1992 tot stand gekomen als reactie op toenemende zorgen over illegale migratie en grensoverschrijdende criminaliteit als gevolg van het wegvallen van de binnengrenzen in het Schengengebied. Niettemin was het instrument oorspronkelijk enkel gericht op vreemdelingentoezicht, zoals ook blijkt uit de oorspronkelijke naam Mobiel Toezicht Vreemdelingen. Omdat al snel bleek dat de KMar tijdens het uitvoeren van het MTV ook regelmatig te maken kreeg met strafbare feiten, werd in 2006 besloten de officiële doelstelling uit te breiden met het bestrijden van de aan migratie gerelateerde criminaliteitsvormen mensensmokkel en identiteitsfraude. Ondanks dat het MTV primair een vorm van vreemdelingentoezicht bleef, vond er in de jaren na deze aanpassing ook een naamswijziging plaats: in plaats van Mobiel Toezicht Vreemdelingen wordt er sindsdien gesproken over Mobiel Toezicht Veiligheid, aanvankelijk enkel in het beleidsdiscours maar inmiddels ook in de wet. Dit lijkt in ieder geval symbolisch het zwaartepunt te verleggen van vreemdelingentoezicht naar strafrechtelijke handhaving (Van der Woude et al., 2015).

Hoewel er ook MTV-controles worden uitgevoerd in internationale treinen, op vliegvelden en op het water, staat in deze bijdrage het MTV zoals dat wordt uitgevoerd op de wegen centraal. Zoals omschreven in artikel 4.17a Vreemdelingenbesluit vinden deze controles plaats in een gebied van twintig kilometer binnen de landsgrenzen met België en Duitsland. Om te voorkomen dat ze het effect hebben van grenscontroles, mag er per weg maximaal zes uur per dag en negentig uur 
per maand gecontroleerd worden. ${ }^{2}$ Tijdens een reguliere, 'statische' MTV-controle observeert een of observeren meerdere motorrijders net na de grens het passerende verkeer en selecteert/selecteren potentieel interessante voertuigen. De motorrijder begeleidt deze voertuigen vervolgens naar de zogenoemde 'controlelocatie' iets verder landinwaarts, waar andere marechaussees de daadwerkelijke controle uitvoeren. In enkele gevallen - de zogeheten 'dynamische controles' wordt echter zowel de selectie als de controle gedaan door marechaussees die in dienstauto's in het grensgebied rondrijden.

Het MTV kent twee belangrijke discretionaire beslismomenten. Het eerste moment is de beslissing om een voertuig te selecteren voor een controle, ofwel de selectiebeslissing. Een redelijk vermoeden van illegaal verblijf of een strafbaar feit is geen voorwaarde voor het selecteren van een voertuig. In de vreemdelingenwetgeving staat enkel aangegeven dat de controles worden uitgevoerd 'op basis van informatie of ervaringsgegevens over illegaal verblijf na grensoverschrijding'. 3 Behalve de internationale en nationale non-discriminatiebeginselen geeft de circulaire geen concrete beperkingen ten aanzien van het selecteren van een voertuig (Van der Woude, Brouwer \& Dekkers, 2016). Marechaussees hebben dus veel vrijheid om zelf in te schatten welke personen en voertuigen mogelijk 'interessant' zijn en gecontroleerd moeten worden.

Het tweede beslismoment vindt plaats nadat een voertuig geselecteerd is voor een controle en betreft de beslissing om een geselecteerd voertuig of persoon nader te onderzoeken. Tijdens de controle worden de inzittenden gecontroleerd op identiteit, nationaliteit en eventueel rechtmatig verblijf in Nederland. ${ }^{4}$ Indien zij middels geldige documenten die drie elementen kunnen aantonen, is de controle klaar en mogen zij doorrijden. Als een of meerdere inzittenden echter niet over geldige documenten beschikken, mogen de marechaussees de auto en eventueel de persoon/personen nader onderzoeken, met het doel om alsnog op enige wijze (bijvoorbeeld door het aantreffen van documenten) de nationaliteit en identiteit van diegene vast te stellen. ${ }^{5}$ Daarnaast is het de marechaussees als algemeen opsporingsambtenaar middels de voortgezette toepassing van bevoegdheden (Corstens \& Borgers, 2014) toegestaan om, indien zij tijdens het uitvoeren van een MTV-controle op spontane wijze stuiten op een concrete verdenking van een strafbaar feit, over te stappen van vreemdelingentoezicht naar opsporing. Op zo'n moment wisselt de desbetreffende marechaussee van 'vreemdelingenrechtelijke pet' naar 'strafvorderlijke pet' (Van der Woude et al., 2015).

Het MTV past dus in veel opzichten duidelijk binnen de eerder beschreven trend van crimmigratie. Het wordt uitgevoerd door marechaussees die veel discretionaire ruimte hebben en over het algemeen weinig verantwoording hoeven af te leggen over de genomen beslissingen. Daarnaast heeft het instrument een complexe juridische grondslag, waaruit een enigszins ambigue doelstelling naar voren

2 Volgens art. 4.17b Vb kan er onder uitzonderlijke omstandigheden van deze limiet worden afgeweken. Hieronder valt ook een verhoogde instroom van vreemdelingen. Sinds november 2016 is daarom de inzet van het MTV geïntensiveerd.

3 Art. 4.17a lid $2 \mathrm{Vb} 2000$.

4 Art. 50 lid 1 VW 2000.

5 Art. 50 lid 1 VW jo. art. 50 lid 5 VW jo. art. A2/3 Vc 2013. 
Op de grens van het vreemdelingentoezicht: discretionaire beslissingen binnen het Mobiel Toezicht Veiligheid

komt die zowel op vreemdelingentoezicht als (beperkte) strafrechtelijke handhaving is gericht. Daar komt de naamswijziging in de officiële beleidsstukken nog bij. Dit alles lijkt de discretionaire ruimte van de uitvoerende marechaussees te vergroten en ruimte te bieden om een eigen beroepsopvatting te ontwikkelen en daarnaar te handelen. Voordat we ingaan op de vraag in hoeverre daar ook daadwerkelijk sprake van is, zullen we eerst een beschrijving geven van de gehanteerde methoden van onderzoek.

\section{Methoden van onderzoek}

Voor deze bijdrage wordt gebruikgemaakt van data die middels verschillende onderzoeksmethoden zijn verzameld in het kader van het onderzoeksproject 'Beslissen in Grensgebieden' tussen oktober 2013 en november 2015 (Van der Woude et al., 2016). ${ }^{6}$ Gedurende deze periode hebben onderzoekers onder andere 57 MTV-diensten meegelopen, resulterend in ruim 800 manuur aan observaties. Er is gekozen voor observatieonderzoek, omdat het een methode is die bij uitstek geschikt is om het gedrag van politieagenten en andere street level ambtenaren in een 'natuurlijke' setting te bestuderen en daardoor inzicht te verkrijgen in hun acties en beslissingen en de wijze waarop die geïnterpreteerd moeten worden (Ley, 1988; Reiss, 1971). Het nadeel dat onderzoekers met hun aanwezigheid het gedrag van de te observeren personen kunnen beïnvloeden (Spano, 2005) is getracht te ondervangen door bij elke brigade minimaal zes diensten mee te draaien, waardoor veel marechaussees zeer regelmatig zijn gezien en gesproken en er een zekere mate van vertrouwen ontstond. Bij het MTV op de weg zijn in totaal vijf brigades van uiteenlopende grootte betrokken.

Onderzoekers waren altijd met twee personen en woonden de volledige dienst bij. Het aantal marechaussees per dienst verschilde sterk, variërend van controles met slechts vier marechaussees tot grote controles met meer dan tien marechaussees en een enkele keer ook ketenpartners. Een dienst duurde normaal gesproken zes tot acht uur en begon altijd met een briefing. De onderzoekers maakten gebruik van dit moment om zichzelf te introduceren, het onderzoek kort toe te lichten en de mogelijkheid te bieden om vragen te stellen. Observaties vonden op verschillende manieren plaats. In de meeste gevallen stonden de onderzoekers op de controlelocatie, waar zij goed zicht hadden op de geselecteerde voertuigen die werden binnengebracht en het verloop van de controle. Tijdens dynamische controles zaten de onderzoekers doorgaans achter in de auto.

Tijdens het meelopen zelf werd er niet alleen geobserveerd, maar werd er ook veel gesproken met de aanwezige marechaussees. Op deze manier is inzicht verkregen in zowel de daadwerkelijk beslissingen van marechaussees als hun interpretaties

6 De verzamelde data voor dit project bestaan uit 800 manuur aan observaties, dertien focusgroepgesprekken met marechaussees betrokken bij de operationele uitvoering van het MTV, 167 surveys afgenomen onder mensen die in het kader van het MTV gecontroleerd werden en achttien diepte-interviews met stafleden, beleidsmedewerkers en ambtenaren werkzaam bij de Koninklijke Marechaussee, het ministerie van Defensie en het ministerie van Veiligheid en Justitie. Voor deze bijdrage is enkel gebruikgemaakt van de observatiedata en de focusgroepgesprekken. 
daarvan. Doordat er vaak meerdere functionarissen op de controlelocatie aanwezig waren is er met veel verschillende marechaussees gesproken. Dit waren gesprekken met een vrij informeel karakter, zonder vooraf opgestelde itemlijst. Doordat dit soort gesprekken bovendien plaatsvonden in een voor de marechaussees vertrouwde omgeving is de kans op sociaalwenselijke antwoorden verkleind. De onderzoekers hielden veldnotities bij in de vorm van korte aantekeningen en steekwoorden, die na afloop van elke dienst verder werden uitgewerkt tot verslagen.

Naast deze observaties zijn er dertien focusgroepgesprekken gevoerd met telkens acht tot tien marechaussees met diverse leeftijden en dienstjaren die betrokken waren bij de operationele uitvoering van het MTV. Focusgroepen kunnen moeilijk te grijpen of vage verschijnselen - zoals de wijze waarop marechaussees invulling geven aan hun discretionaire beslisruimte - inzichtelijk maken, evenals de invloed van en dynamiek binnen de onderzochte groep (Finch, Lewis \& Turley, 2013; Krueger \& Casey, 2014). Bij de meeste brigades hebben twee focusgroepgesprekken plaatsgevonden, bij één brigade één en bij een grotere brigade vier. Deze gesprekken vonden plaats nadat het grootste deel van de observaties reeds was uitgevoerd, waardoor onderwerpen en voorlopige bevindingen die tijdens de observaties naar voren kwamen ter reflectie aan de deelnemers konden worden voorgelegd. Dit zorgde voor een verrijking en verdieping van de data. Zo is er tijdens deze gesprekken uitgebreid ingegaan op de percepties van de marechaussees ten aanzien van de eigen taakstelling en de daarbij behorende bevoegdheden. Focusgroepen zijn daarvoor bij uitstek geschikt, omdat ze data opleveren die een goed inzicht geven in de collectieve opvattingen van een homogene groep.

De focusgroepgesprekken zijn opgenomen en woordelijk getranscribeerd. Alle veldnotities en interviewtranscripten zijn vervolgens gecodeerd en geanalyseerd met behulp van Atlas-Ti. Hierbij is gebruikgemaakt van een door de onderzoekers vooraf opgestelde lijst met codes die tijdens het coderen zelf - en in onderling overleg - nog is aangevuld en aangepast.

\section{Tussen vreemdelingentoezicht en strafrechtelijke handhaving}

Tijdens het veldwerk werd duidelijk dat er onder de marechaussees op straatniveau verschillende visies bestonden op de eigen taakstelling. Bijna alle marechaussees gaven aan dat het MTV vooral een instrument is voor vreemdelingentoezicht en noemden de bestrijding van illegale migratie als belangrijke of belangrijkste doelstelling. Tegelijkertijd zijn marechaussees volgens artikel 141 Wetboek van Strafvordering ook algemeen opsporingsambtenaar, waardoor zij bevoegd zijn tot strafrechtelijke handhaving als zij, conform de hiervoor reeds genoemde leer van de voortgezette toepassing, tijdens een controle spontaan op iets strafbaars anders dan mensensmokkel of ID-fraude stuiten. Veel respondenten zagen zichzelf dan ook uitdrukkelijk als meer dan enkel toezichthouders in het kader van de Vreemdelingenwet en vonden behalve mensenmokkel en identiteitsfraude ook andere vormen van criminaliteit belangrijk. Onder andere drugscriminaliteit, witwassen en wapenbezit werden vaak genoemd. Sommige van deze 
Op de grens van het vreemdelingentoezicht: discretionaire beslissingen binnen het Mobiel Toezicht Veiligheid

respondenten zagen zich hierin gesteund door de naamswijziging van het MTV. Ondanks dat deze verandering niet gepaard is gegaan met feitelijke veranderingen in de doelstelling van het MTV of de taakstelling van de marechaussees, was een deel van de respondenten niettemin van mening dat het meer dan slechts een semantische wijziging betrof.

'Binnen die 20km zone ben je niet meer specifiek bezig op vreemdelingen, je bent ook met veiligheid bezig. Daar zit een andere benaming aan (...) Je hebt ook dingen als witwassen en zo waar je op let.'

Respondenten gaven aan voor zichzelf een belangrijke rol te zien weggelegd in het beschermen van de Nederlandse staat tegen allerlei vormen van gevaar. Zo vertelde een van de marechaussees dat werd geprobeerd niet te veel op drugsrunners te selecteren, maar dat dat nog weleens lastig was omdat marechaussees toch allemaal 'blauw bloed' hebben. Daarnaast werd regelmatig bij aanvang van een dienst gesteld dat ze vandaag weer gingen proberen om 'boeven te vangen'. In die zin lijken de marechaussees weinig te verschillen van reguliere politieagenten, die 'boeven vangen' als hun belangrijkste taak zien (Kleijer-Kool \& Landman, 2016; Landman, 2015). Een logisch gevolg van zichzelf zo uitdrukkelijk positioneren als criminaliteitsbestrijder was dat de taakstelling breed wordt opgevat. Zoals een van de marechaussees aangaf tijdens een focusgroepgesprek:

'De politie is van de veiligheid op de straat en de KMar voor de veiligheid van de staat. Daaronder valt dus ook het pakken van lui die als vuurwapengevaarlijk, vluchtgevaarlijk of in verband met drugs gesignaleerd staan.'

Deze bredere interpretatie van het doel van het MTV leek deels voort te komen uit de gedachte dat wanneer men zich enkel op de bij wet voorgeschreven delicten zou richten, dit een onnodige beperking zou oplevering van de aanwezigheid van de marechaussee in de grensgebieden. Veel marechaussees waren van mening dat het een verspilling van capaciteit zou zijn om het MTV enkel in te zetten voor het vreemdelingentoezicht.

'We zijn algemeen opsporingsambtenaren en we staan daar toch [in de grensgebieden, JB]. We staan er en ik denk dan, laten we die zes uur die we daar mogen staan maximaal benutten in plaats van de ogen [te] sluiten voor de helft.'

Er bestonden al met al - in lijn met de verwachtingen op grond van de theoretische literatuur - wezenlijke verschillen tussen de marechaussees in de visie over de precieze reikwijdte van de doelstelling van het MTV en de wijze waarop zij hun taak zagen. Vergelijkbaar met de verschillende politiestijlen die bij de reguliere politie zijn geïdentificeerd (Terpstra \& Schaap, 2011), werd in dit verband soms ook wel gesproken over een onderscheid tussen vreemdelingenmensen en politiemensen. Hiermee werd gedoeld op het feit dat sommige marechaussees zich voornamelijk richtten op vreemdelingrechtelijke zaken, terwijl anderen juist meer 
geïnteresseerd waren in het tegengaan van criminaliteit. Tegelijkertijd waren er ook veel marechaussees die weinig onderscheid hierin maakten en aangaven het allebei als een belangrijk onderdeel van hun taak te zien. Dit leidde ertoe dat criminelen en vreemdelingen soms in één adem werden genoemd en van een helder onderscheid niet altijd sprake was.

'Je hebt mensen, ik ben er zelf ook eentje van, ik pak alles wat me voor de voeten komt. Het interesseert me niet of het nou een vreemdeling is, of artikel 8 [Wegenverkeerswet, JB] of een wapen of een onverzekerde auto, dat maakt me niets uit. Kijk ik wil gewoon een boef vangen en of dat nou een vreemdeling is zeg maar of wat anders, dat maakt mij niet uit.'

Vooral de jongere marechaussees leken het 'boeven vangen' vaak spannender te vinden dan het controleren van mogelijk illegale vreemdelingen. Regelmatig werd ook aangegeven dat men de meeste voldoening haalde uit het aantreffen van de meer strafrechtelijke zaken. Nadat een van de marechaussees een auto had gecontroleerd omdat hij dacht dat de inzittenden Albanezen waren, zei hij dat hij van mening was dat Albanezen vaak betrokken zijn bij criminaliteit en dat hij veel liever dat soort types aanpakt dan een illegale Afrikaan. Dat veel marechaussees vooral graag voor de strafrechtelijke zaken gingen, bleek herhaaldelijk tijdens de geobserveerde controles. Het gebeurde regelmatig dat een voertuig werd gestopt dat volgens de marechaussees niet bepaald interessant was in vreemdelingrechtelijk opzicht, maar waarvan de inzittenden mogelijk nog boetes hadden openstaan of simpelweg 'een boevenkop' hadden. Voor veel marechaussees was het vangen van een boef hetgeen het werk de moeite waard maakte en verhalen over een opgepakte crimineel werden vaak veelvuldig verteld. Ook dit sluit aan bij de bevindingen uit onderzoek naar reguliere politieagenten, waaruit naar voren komt dat de aanwezigheid van 'boeven' een cruciale factor is van hun werkplezier (Kleijer-Kool \& Landman, 2016). De marechaussees werden daarnaast vaak zichtbaar enthousiast als er een auto werd gecontroleerd waarvan de inzittenden antecedenten hadden of gesignaleerd stonden.

Een concrete casus kan dit illustreren. Tijdens een van de controles werd een taxi gecontroleerd met twee jonge jongens van een jaar of twaalf achterin. Zij hadden geen identiteitspapieren bij, maar zeiden Duits en Kroatisch te zijn. Ze beweerden onderweg te zijn naar hun oma om een ziekenhuisrekening te betalen en daarvoor geld te hebben gekregen van hun moeder. De aanwezige marechaussees gaven aan weinig van het verhaal te geloven en toen er tijdens het doorzoeken van de spullen in de kofferbak een doorzichtige zak vol gouden juwelen in een groot brood werd aangetroffen, ontstond er duidelijk lichte euforie onder de marechaussees over deze grote vondst, hetgeen zich uitte door onderlinge felicitaties en het uitdelen van 'boksen'. In de weken daarna werd er op de desbetreffende brigade nog regelmatig gerefereerd aan deze zaak. 
Op de grens van het vreemdelingentoezicht: discretionaire beslissingen binnen het Mobiel Toezicht Veiligheid

\section{Beslissen in een ambigue context}

Doordat voor het stoppen van een voertuig in het kader van MTV, anders dan bij het binnenlands vreemdelingentoezicht, het niet noodzakelijk is dat er sprake is van een redelijk vermoeden van illegaal verblijf, hebben individuele marechaussees veel ruimte om zelf te beslissen wie zij selecteren voor een controle. Tijdens het veldwerk werd duidelijk dat marechaussees niet alleen veel discretie hebben in hun beslissingen om voertuigen te stoppen, maar ook om te beslissen of een gestopt voertuig of persoon nader onderzocht wordt. Indien iemand niet de juiste papieren bij zich heeft, moet worden beslist of er wel of geen onderzoek naar deze persoon wordt ingesteld en of de auto wel of niet wordt doorzocht. Soms wordt deze beslissing gebaseerd op een inschatting van de kans dat iemand illegaal in het land is. Dit was bijvoorbeeld het geval toen twee Duitse jongens met een Noord-Afrikaans uiterlijk werden gecontroleerd en geen paspoort bij zich hadden. De controlerende marechaussee besloot vrij snel om ze door te laten rijden, omdat ze geen 'immigranten-Duits' spraken en een van hen wel het Duitse paspoort van zijn broer bij zich had. Vaak ook werd de beslissing gebaseerd op de mogelijkheid dat er iets strafbaars wordt aangetroffen. Toen een auto met vier Oost-Europese jongemannen werd doorzocht omdat een van hen geen paspoort bij zich had, gaf een van de aanwezige marechaussees aan dat dit niet zou gebeuren als er een ouder echtpaar of een degelijk gezinnetje in zou zitten, omdat in dat geval de kans op het aantreffen van iets strafbaars immers aanzienlijk kleiner zou zijn. Een andere keer werd een voertuig met een Nederlands kenteken en drie Nederlands sprekende mannen volledig doorzocht nadat de bestuurder enkel een Nederlands rijbewijs kon overleggen (wat geen geldig grensoverschrijdend document is), omdat de mannen, woonachtig op een woonwagenkamp in de buurt, bekend waren bij de marechaussee in verband met criminaliteit.

Een belangrijke factor die van invloed is op de wijze waarop marechaussees hun discretionaire ruimte invullen, is de wijze waarop zij hun eigen taak zien. Zoals hiervoor uiteengezet, is het MTV ondanks de naamswijziging in essentie nog steeds een instrument dat primair is gericht op vreemdelingentoezicht, hetgeen is terug te zien in de bevoegdheden van de marechaussees. Zij hebben volgens artikel 50 VW 2000 geen bevoegdheid om een voertuig te doorzoeken indien alle inzittenden geldige identiteitspapieren kunnen overleggen. Deze beperking ten aanzien van het doorzoeken van een voertuig leverde regelmatig frustraties op wanneer marechaussees het gevoel hadden dat er iets niet in orde was, maar op basis van hun bevoegdheden niet mochten overgaan tot bijvoorbeeld het openen van de kofferbak.

'Dat is het enige nadeel dat wij daar op basis van de vreemdelingenwet staan. Als wij de papieren hebben houdt het voor ons op en dan zou je al niet meer in de auto mogen kijken. Of hij staat toevallig voor drugs of vuurwapengevaar en dan kun je heel die auto binnenste buiten keren, maar verder heb je eigenlijk geen grond om inderdaad de kofferbak open te trekken.' 
Ondanks dit soort frustraties gaven sommige marechaussees aan dat ze niet anders konden dan zich hierbij neer te leggen. Hier werd echter anders tegenaan gekeken door respondenten die van mening waren dat zij een bredere taakstelling hadden of in ieder geval zouden moeten hebben. Regelmatig gaven marechaussees aan dat zij zich niet konden vinden in de beperkingen van de vreemdelingenwetgeving, omdat de bevoegdheden tekortschoten om echt op veiligheid te controleren.

'Ik snap niet waarom ze zo moeilijk doen over die kofferbakken, waarom passen ze dat niet gewoon aan? Laat ons daar gewoon in kijken, want het gaat tenslotte gewoon om de veiligheid.'

Om deze beperking te ondervangen gaven verschillende respondenten aan dat zij 'creatief' met hun bevoegdheden moesten omgaan. Cruciaal hierbij is dat marechaussees zelf aangaven niet per se de regels te overtreden of misbruik te maken van hun bevoegdheden; in plaats daarvan stelden zij dat ze slechts optimaal gebruikmaakten van de mogelijkheden die de verschillende vormen van wetgeving bieden. Dit kan goed geillustreerd worden middels een concrete casus. Tegen het eind van een dynamische controle werd in een woonwijk een stationwagen gestopt met een vrij jonge jongen achter het stuur, zonder zichtbaar concrete aanleiding (hetgeen bij latere navraag door de marechaussees werd bevestigd). Tijdens de controle bleek dat hij nog een aantal boetes had openstaan en werd hij meegenomen naar de brigade om het verder af te handelen. Onderweg vroeg de jongen aan een van de marechaussees waarom ze hem gestopt hadden, waarop deze antwoordde dat hij was gestopt omdat hij zijn knipperlicht niet had aangedaan. Later op de brigade legde de marechaussee aan de onderzoekers uit dat hij altijd op zoek was naar een ingang, hoe klein ook, en dat ze in dit geval een controle op basis van de Wegenverkeerswet zouden gebruiken.

De marechaussee is natuurlijk niet uniek in dit creatief gebruikmaken van bevoegdheden en verschillende wetgeving; ook bij onderzoek bij de politie komt dit naar voren (Halderen \& Lasthuizen, 2013). Niettemin biedt de combinatie van vreemdelingrechtelijke en strafrechtelijke bevoegdheden de marechaussee extra veel mogelijkheden om op te treden. Regelmatig verwezen de marechaussees expliciet naar de mogelijkheid om verschillende vormen van wetgeving te gebruiken.

'Nou, als ik een auto controleer dan kijk ik eerst naar de documenten, maar je bent ook al direct in het voertuig aan het kijken. Als je iets ruikt dan trek je die hele auto open op het gebied van opium. Als je in de deurpost kijkt, misschien zie je daar een wapen liggen en als ze geen documenten hebben, dan trek je de heel de auto ondersteboven, dus zo moet je een beetje met die wetgeving spelen en zo kom je ook de leuke dingen tegen.'

Zoals aangegeven in het theoretisch gedeelte kunnen meer regels en wetten paradoxaal genoeg leiden tot meer discretie, en veel marechaussees bleken inderdaad juist mogelijkheden te zien in het combineren van de voordelen van vreemdelin- 
Op de grens van het vreemdelingentoezicht: discretionaire beslissingen binnen het Mobiel Toezicht Veiligheid

gentoezicht en strafrechtelijke handhaving. De vraag of de wetgeving op die manier ook altijd juist werd gebruikt, leek daarbij niet centraal te staan. In lijn met het idee van ad hoc instrumentalisme maakten zij gebruik van de wetgeving die het meest effectief was in een bepaalde situatie. Handhaving via het strafrecht is echter met aanzienlijk meer rechtswaarborgen omkleed dan toezicht middels het bestuursrecht. Zo maakt de vreemdelingenwet het mogelijk om in het kader van het MTV een voertuig te stoppen en alle inzittenden te controleren zonder redelijk vermoeden van illegaal verblijf of een strafbaar feit. Vervolgens kan er op basis van zowel het ontbreken van de juiste papieren als een verdenking van een strafbaar feit besloten worden om een persoon of voertuig nader te onderzoeken. Zoals een van de respondenten uitlegde:

'We zijn ambtenaar belast met grenstoezicht en dat is geregeld in de bestuurswet en dan zijn we gewoon toezichthouders. Het mooie van de vreemdelingenwetgeving is natuurlijk dat je iedereen mag controleren, want anders is het alleen de bestuurder. (...) En als eentje iets niet bij zich heeft kun je op artikel 50 [VW, JB] ook het voertuig doorzoeken en dan is het natuurlijk stuiten op, ik pak als voorbeeld maar marihuana, en dan zet je je politiepet op. Voortzetten van het toepassen van je bevoegdheden en dan word je ineens van toezichthouder word je opsporingsambtenaar.'

Tegelijkertijd waren er op dit gebied evidente verschillen tussen brigades en zelfs tussen individuele marechaussees per brigade. Deze verschillen werden soms ingegeven door onduidelijkheid over de doelstelling van het MTV en hoever de eigen bevoegdheden reikten. Zo opende tijdens een van de geobserveerde diensten de teamleider een kofferbak naar aanleiding van de aanwezigheid van lange vloei (een stukje papier met plakrand waarmee vaak joints worden gerold) in de auto. Een van de aanwezige marechaussees vroeg daarop aan een meer ervaren collega of de aanwezigheid van lange vloei inderdaad voldoende reden was om de kofferbak te doorzoeken, waarop deze aangaf dat dit niet het geval was. Zeker als er geen wietgeur aanwezig was en de bestuurder rode ogen had was dit niet voldoende, omdat lange vloei op zichzelf nu eenmaal niet verboden is. Hierop gaf de jongere marechaussee aan dat dat ook zijn mening was, maar dat hij was gaan twijfelen nadat hij de teamleider dit had zien doen.

\section{Conclusie}

In deze bijdrage hebben we gekeken naar de wijze waarop street level marechaussees die het MTV uitvoeren invulling geven aan hun discretionaire ruimte. Deze marechaussees hebben veel discretionaire ruimte om de officiële beleidsdoelen om te zetten naar daadwerkelijk handelen. Tegelijkertijd zijn deze beleidsdoelen enigszins ambigu: het MTV kent een complex juridisch kader waarin vreemdelingentoezicht overlapt met strafrechtelijke handhaving, hetgeen wordt versterkt door de naamswijziging van Mobiel Toezicht Vreemdelingen naar Mobiel Toezicht Veiligheid. Passend binnen het proces van crimmigratie en ad hoc instru- 
mentalisme vergroot dit de discretionaire ruimte van de uitvoerende marechaussees en maakt het mogelijk om eigen beroepsopvattingen en overtuigingen een rol te laten spelen bij beslissingen.

Uit de resultaten blijkt dat marechaussees in de praktijk inderdaad laveren tussen vreemdelingentoezicht en strafrechtelijke handhaving. Zij proberen daarin hun eigen weg te vinden, waarbij eenieder andere accenten legt. Net als bij reguliere politieagenten bestaan er daardoor onder de marechaussees die het MTV uitvoeren verschillende stijlen: een deel richt zich vooral op het vreemdelingentoezicht, terwijl een ander deel meer gefocust lijkt te zijn op het tegengaan van criminaliteit en sterk wordt gedreven door de wens om de veiligheid van de Nederlandse staat te vergroten. Marechaussees in deze laatste groep vinden het 'boeven vangen' spannender en halen daar meer voldoening uit dan uit het toezicht houden op mogelijk illegale vreemdelingen, hetgeen lijkt te passen binnen het idee van het streven naar rechtvaardigheid.

De eigen beroepsopvatting heeft concrete gevolgen voor de wijze waarop met de discretionaire beslisruimte en de bijbehorende bevoegdheden wordt omgegaan. Zoals in het theoretisch gedeelte is uiteengezet, kunnen meer regels en wetten juist leiden tot meer discretie, doordat street level ambtenaren simpelweg meer mogelijkheden hebben om uit te kiezen. In het kader van het MTV bleek zelfs de veronderstelling van meer regels, in combinatie met een ambigue doelstelling, al in meer discretionaire beslisruimte te resulteren. Doordat het MTV nog steeds primair een instrument voor vreemdelingentoezicht is, waren vooral de 'politiemensen' onder de marechaussees van mening dat de bestaande bevoegdheden soms onvoldoende mogelijkheden bieden. Om deze doelen toch te bereiken maakten zij regelmatig op creatieve wijze gebruik van hun bevoegdheden, waarbij er 'gespeeld' werd met de verschillende wetsgebieden. ${ }^{7}$ Dit past binnen het beeld van crimmigratie en ad hoc instrumentalisme: zowel ongewenste migranten als criminelen worden aangepakt door middel van het meest effectieve middel voorhanden, ongeacht uit welk rechtsgebied dat komt. Op die manier draagt het optreden van de marechaussees dus bij aan het verder vervagen van de grens tussen vreemdelingentoezicht en strafrechtelijke handhaving.

Zowel de nadruk op 'boeven vangen' als het creatief gebruik van bevoegdheden komt ook naar voren uit onderzoek bij de politie (Halderen \& Lasthuizen, 2013; Kleijer-Kool \& Landman, 2016). Wat de marechaussees echter onderscheidt van de reguliere politie is de combinatie van vreemdelingentoezicht en strafrechtelijke handhaving van het MTV. Door de vervlechting van vreemdelingentoezicht en strafrechtelijke handhaving beschikken zij over een uitgebreidere gereedschapskist met instrumenten die ze kunnen inzetten tijdens een controle, met

7 Op 1 november 2016 heeft de Hoge Raad zich uitgesproken over het creatief omgaan met bevoegdheden door de Nationale Politie. In het kader van de dynamische verkeerscontroles was er volgens de Hoge Raad geen sprake van misbruik van bevoegdheden - een kwalijk creatief gebruik van bevoegdheden - aangezien niet kon worden vastgesteld dat de controlebevoegdheid uitsluitend voor opsporingsdoeleinden was gebruikt. HR 1 november 2016, ECLI:NL:HR: 2016:2454. Deze uitspraak van de Hoge Raad noopt tot nuance over de - juridische - verwerpelijkheid ten aanzien van het waargenomen creatief gebruik van bevoegdheden door de Koninklijke Marechaussee in de context van het MTV. 
Op de grens van het vreemdelingentoezicht: discretionaire beslissingen binnen het Mobiel Toezicht Veiligheid

bevoegdheden die voortvloeien uit zowel het bestuursrecht als het strafrecht. Marechaussees beschikken aldus over een veelvoud aan mogelijkheden om een voertuig te stoppen en nader te onderzoeken. In overeenkomst met Sklansky's (2012) ad hoc instrumentalisme en de beweringen van Maynard-Moody en Musheno (2000) kunnen zij eerst een oordeel vormen over een voertuig of persoon en vervolgens gebruikmaken van een van de mogelijkheden uit de uitgebreide gereedschapskist die zij tot hun beschikking hebben om daar hun beslissingen op te baseren. Dit leidt ertoe dat het niet altijd transparant is op welke grond een bepaalde beslissing gebaseerd is, al helemaal niet voor de personen die gecontroleerd worden. Handhaving via het strafrecht is bovendien met aanzienlijk meer rechtswaarborgen omkleed dan toezicht middels het bestuursrecht.

Hoewel het voorliggende artikel vooral gericht was op een empirische bestudering van uitvoeringsbeslissingen rijst wel de normatieve vraag of deze combinatie van controlebevoegdheden - zo typerend voor het proces van crimmigratie - wenselijk is met het oog op een gelijke behandeling van gecontroleerde personen en de bescherming van de rechtszekerheid en zo ja, in hoeverre voldoende waarborgen zijn ingebouwd. Waar discretionaire ruimte voor uitvoerenden nodig kan zijn om abstracte regels te kunnen vertalen naar concrete situaties, dienen dergelijke fundamentele afwegingen niet te worden overgelaten aan het niveau van de uitvoering.

\section{Literatuur}

Aas, K.F. \& H.O.I. Gundhus (2015) Policing humanitarian borderlands: Frontex, human rights and the precariousness of life. British Journal of Criminology, 55(1), 1-18.

Alpert, G.P., J.M. Macdonald \& R.G. Dunham (2005) Police suspicion and discretionary decision making during citizen stops. Criminology, 43(2), 407-434.

Bastien, J. (2009) Goal ambiguity and informal discretion in the implementation of public policies: the case of Spanish immigration policy. International Review of Administrative Sciences, 75(4), 665-685.

Brown, M.K. (1981) Working the Street: Police Discretion and the Dilemmas of Reform. New York: Russell Sage Found.

Casella Colombeau, S. (2017) Policing the internal Schengen borders - managing the double bind between free movement and migration control. Policing and Society, 14(1), 63-77.

Corstens, G.J.M. \& M.J. Borgers (2014) Het Nederlands strafprocesrecht (8th ed.). Deventer: Kluwer.

Cote-Boucher, K., F. Infantino \& M.B. Salter (2014) Border security as practice: an agenda for research. Security Dialogue, 45(3), 195-208.

De Maillard, J., D. Hunold, S. Roché \& D. Oberwittler (2016) Different styles of policing: discretionary power in street controls by the public police in France and Germany. Policing and Society, 1-14.

Dekkers, T.J.M. \& M.A.H. van der Woude (2014) Staring at the felony forest. De complexiteit van risicoprofilering nader in kaart gebracht. Proces, 93(93), 52-70.

Dunham, R.G. (2005) Transforming citizens into suspects: factors that influence the formation of police suspicion. Police Quarterly, 8, 366-393. 
Finch, H., J. Lewis \& C. Turley (2013) Focus Groups. In J. Richtie, C. Lewis, N. McNaughton \& R. Ormston (Eds.), Qualitative Research Practice: A Guide for Social Science Students and Researchers (p. 211-242). Thousand Oaks, CA: Sage.

Halderen, R.C. van \& K. Lasthuizen (2013) Creatief gebruik van bevoegdheden. Tijdschrift voor Veiligheid, 2013(12), 16-36.

Hawkins, K. (2014) Order rationality and silence: some reflections on criminal justice decision-making. In L. Gelsthorpe \& N. Padfield (Eds.), Exercising discretion: some reflections on criminal justice decision-making (p. 186-219). London: Routledge.

Johnson, R.R. \& M.A. Morgan (2013) Suspicion formation among police officers: an international literature review. Criminal Justice Studies: A Critical Journal of Crime, Law and Society, 26(1), 99-114.

Kleijer-Kool, L. (2010) Politiestijlen en conflictpotentieel in multiculturele achterstandswijken. In F. Bovenkerk, M. Easton, P. Ponsaers \& L.G. Moor (Eds.), Policing multiple communities (Cahiers Politiestudies 15) (p. 69-86). Gent: Maklu.

Kleijer-Kool, L. \& W. Landman (2016) 'Boeven vangen'. Het spel tussen politieagenten en de Ander. Tijdschrift over Cultuur \& Criminaliteit, 6(1), 42-65.

Krueger, R.A. \& M.A. Casey (2014) Focus groups: A practical guide for applied research. Thousand Oaks, CA: Sage.

Landman, W. (2015) Blauwe patronen. Betekenisgeving in politiewerk. Den Haag: Boom Lemma.

Ley, D. (1988) Interpretive social research in the inner city. In J. Eyles (Ed.), Research in Human Geography. Introductions and Investigations (p. 121-138), Oxford: Blackwell.

Lipsky, M. (1980) Street level bureaucracy: dilemmas of the individual in public services. New York: Russel Sage Foundation.

Loftus, B. (2015) Border regimes and the sociology of policing. Policing and Society: An International Journal of Research and Policy, 25(1), 115-125.

Maynard-Moody, S. \& M. Musheno (2000) State Agent or Citizen Agent: Two Narratives of Discretion. Journal of Public Administration Research and Theory, 10, 329-358.

Mendias, C. \& E.J. Kehoe (2006) Engagement of policing ideals and their relationship to the exercise of discretionary powers. Criminal Justice and Behavior, 33(1), 70-92.

Motomura, H. (2011) The discretion that matters: federal immigration enforcement, state and local arrests, and the civil-criminal line. UCLA Law Review, 58, 1819-1858.

Phillips, S.W. (2015) Police Discretion and Boredom: What Officers Do When There Is Nothing to Do. Journal of Contemporary Ethnography, 1-22.

Portillo, S. \& D.S. Rudes (2014) Construction of Justice at the Street Level. Annual Review of Law and Social Science, 10, 321-334.

Pratt, A. (2010) Between a hunch and a hard place: making suspicion reasonable at the Canadian border. Social \& Legal Studies, 19(4), 461-480.

Pratt, A. \& S.K. Thompson (2008) Chivalry, 'race' and discretion at the Canadian border. British Journal of Criminology, 48(5), 620-640.

Quinton, P. (2011) The formation of suspicions: police stop and search practices in England and Wales. Policing and Society, 21(4), 357-368.

Reiss, A.J. (1971) The Police and the Public. New Haven: Yale University Press.

Schneider, C.E. (1992) Discretion and Rules: A Lawyer's View. In K. Hawkins (Ed.), The Uses of Discretion (p. 47-88). Oxford: Clarendon.

Sklansky, D.A. (2012) Crime, immigration, and ad hoc instrumentalism. New Criminal Law Review, 15(2), 157-223.

Spano, R. (2005) Potential sources of observer bias in police observational data. Social Science Research, 34(3), 591-617. 
Op de grens van het vreemdelingentoezicht: discretionaire beslissingen binnen het Mobiel Toezicht Veiligheid

Staring, R. (2012) Crimmigratie en de morele economie van illegale vreemdelingen. Proces, 91(6), 396-407.

Stroshine, M., G.P. Alpert \& R.G. Dunham (2008) The influence of 'working rules' on police suspicion and discretionary decision making. Police Quarterly, 11(3), 315-337.

Stumpf, J.P. (2006) The crimmigration crisis: immigrants, crime, and sovereign power. American University Law Review, 56(2), 367-420.

Terpstra, J. \& D. Schaap (2011) Politiecultuur: een empirische verkenning in de Nederlandse context. Proces, 90(4), 183-196.

Van der Leun, J.P. (2010) Crimmigratie. Apeldoorn/Antwerpen: Maklu.

Van der Leun, J.P. \& M.A.H. van der Woude (2012) A reflection on crimmigration in the Netherlands. On the cultural security complex and the impact of framing. In M. Joao Guia, M. van der Woude \& J. van der Leun (Eds.), Social control and justice: crimmigration in the Age of Fear (p. 41-60). The Hague: Eleven International Publishing.

Van der Leun, J.P., M.A.H. van der Woude \& S. de Ridder (2013) Crimmigratie in de lage landen: smeltende grenzen?. Strafblad, Juli, 221-228.

Van der Torre, E.J. (1999) Politiewerk. Politiestijlen, community policing, professionalisme. Alphen aan den Rijn: Samsom.

Van der Woude, M.A.H., J. Brouwer \& T.J.M. Dekkers (2016) Beslissen in grensgebieden. Een onderzoek naar het Mobiel Toezicht Veiligheid zoals uitgevoerd door de Koninklijke Marechaussee. Den Haag: Boom criminologie.

Van der Woude, M.A.H., T.J.M. Dekkers \& J. Brouwer (2015) Over crimmigratie en discretionair beslissen binnen het Mobiel Toezicht Veiligheid ... of Vreemdelingen ... of Veiligheid?. Tijdschrift Voor Veiligheid, 14(2), 19-35.

Van der Woude, M.A.H., J.P. van der Leun \& J.A. Nijland (2014) Crimmigration in the Netherlands. Law \& Social Inquiry, 39(3), 560-579.

Van Gestel, B. \& C. de Poot (2014) Acute dreigingen, vage geruchten. Tijdschrift Voor Criminologie, 56(4), 71-86.

Weber, L. (2011) 'It sounds like they shouldn't be here': immigration checks on the streets of Sydney. Policing and Society, 21(4), 456-467.

Wilson, J. (1978) Varieties of Police Behavior: The Management of Law and Order in Eight Communities. Cambridge, MA: Harvard University Press. 